MATEC Web of Conferences 52, 03003 (2016)

DOI: $10.1051 /$ matecconf/20165203003

(C) Owned by the authors, published by EDP Sciences, 2016

\title{
The Application of Cloud Innovation in Industrial Design Education
}

\author{
JIANG Li-jun ${ }^{1}$, Song Bo ${ }^{2}$, Su Jing ${ }^{3}$, Li Zhe-lin ${ }^{4, a}$ \\ ${ }^{1}$ School of design, South China University of Technology, Guangzhou 510006, China \\ ${ }^{2}$ School of design, South China University of Technology, Guangzhou 510006, China \\ ${ }^{3}$ Foshan 91Ant network technology co., LTD, Foshan 528000, China \\ ${ }^{4}$ School of design, South China University of Technology, Guangzhou 510006, China
}

\begin{abstract}
According to the domestic status of students' study and practice of industrial design, the application of cloud innovation in industrial design education was proposed to realize online design reviews, dissemination and sharing, virtual display and demand-oriented collaborative design. The basic framework and function of cloud innovation system were analyzed to solve three problems: design relearning, lack of creative communication, separation between education and enterprise production of industrial design.
\end{abstract}

\section{Problems of Learning and Practicing in Industrial Design Education}

The necessity of industrial design innovation is not only passion, intuition and imagination, but also the strong rationality and the right approach. From the practical needs of industry, oriented from the problems, industrial students need to balance creativity with other constraints by design evaluation and design iterations in various stages. Restricted by the domestic objective factors, students of industrial design have many problems in learning and practicing. It is the key to the development of industrial design that how to develop students' creativity effectively combined with the concept of Internet+.

With the popularity of Web2.0 technology, cloud innovation comes to represent the most viable innovation model, which concentrates wisdom of public innovation. To solve the problems of learning and practicing in industrial design education, the needs of the students' professional development were analyzed and the cloud innovation platform was set up and studied.

On the basis of analysis research, three problems were summed up for industrial design students when learning and practicing.

\subsection{Relearning problems with new design task}

As industrial design is interdisciplinary, designers have to design the product in the form, style and emotion with knowledge about materials, technology, beauty, and culture, to realize product innovation with high technology, artistic value and economic worth(as shown in figure 1). It means that the more interdisciplinary knowledge structure, more sophisticated technical support and better innovation theory are needed. Industrial design students encounter relearning problems with new

a Corresponding author : gzwoods@qq.com 
design task. To save learning cost, students need the guidance from experienced people, or team of people with variety knowledge and technical background during the design process.

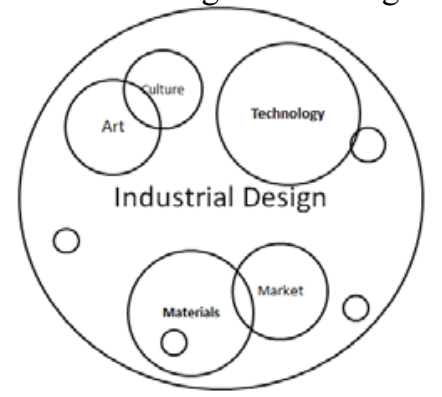

Figure 1. The Relationship Between Industrial Design And Relevant Subjects

\subsection{Lack of innovative communication}

The major of industrial design is set up by many colleges and universities in China. A lot of design works, some of which are quite creative, are sealed in graduation documentation; At the same time, the shortage of design talents for industrial enterprises and design companies need to be solved and a large number of design students cannot obtain employment. Due to the limitation of objective and subjective elements, communication between enterprises and teachers, students from different colleges is not sufficient. The existing closed innovation model is not suitable for most designers.

\subsection{Education separated from practice}

In universities at home, the design theory domestic students learning is relatively old sometimes, and the design practice they make differs from the actual production conditions. Due to the geography and other objective conditions, many students don't have an opportunity to link with companies and only do virtual design exercises at school. As the students can not participate in the the real design process, their design works in school are hard to turn into real products.

\section{Research of the Existing Design Innovation Platform}

For now there are many online design innovation platforms for business and education in domestic and overseas. From the perspective of industrial design education, they all have advantages and disadvantages (examples are shown in table 1).

Table 1. Design Innovation Platform Research

\begin{tabular}{|c|c|c|c|c|c|}
\hline $\begin{array}{l}\text { Platform } \\
\text { name }\end{array}$ & $\begin{array}{l}\text { Platform } \\
\text { type }\end{array}$ & $\begin{array}{l}\text { Basic mode and } \\
\text { functions }\end{array}$ & $\begin{array}{l}\text { Target } \\
\text { audience }\end{array}$ & $\begin{array}{l}\text { Advantages in design } \\
\text { education }\end{array}$ & $\begin{array}{l}\text { Disadvantages in } \\
\text { design education }\end{array}$ \\
\hline $\begin{array}{l}\text { Billwang } \\
\text { (www.billwa } \\
\text { ng.net) }\end{array}$ & $\begin{array}{l}\text { Industrial } \\
\text { design } \\
\text { communi } \\
\text {-ty }\end{array}$ & $\begin{array}{l}\text { To publish and discuss } \\
\text { design work,get } \\
\text { information of design } \\
\text { activities and } \\
\text { recruitment }\end{array}$ & $\begin{array}{l}\text { Industrial } \\
\text { designersin } \\
\text { dustrial } \\
\text { design } \\
\text { students } \\
\end{array}$ & $\begin{array}{l}\text { Professional and } \\
\text { targeted }\end{array}$ & $\begin{array}{l}\text { As most students' design } \\
\text { are in a primary level, } \\
\text { their design works will } \\
\text { not gain enough } \\
\text { attention and advice }\end{array}$ \\
\hline $\begin{array}{l}\text { ZBJ Network } \\
\text { (www.zbj.co } \\
\text { m) }\end{array}$ & $\begin{array}{l}\text { Witkey } \\
\text { Service } \\
\text { Platform }\end{array}$ & $\begin{array}{l}\text { Employers post } \\
\text { requirements, } \\
\text { providers bid and } \\
\text { work on jobs posted } \\
\text { by employers. } \\
\text { Three transaction-al m } \\
\text { odels: reward, bidding } \\
\text { and trading patterns }\end{array}$ & $\begin{array}{l}\text { Enterprises, } \\
\text { social } \\
\text { organizatio } \\
\text { n-s and } \\
\text { individuals; } \\
\text { Witkey, } \\
\text { design insti } \\
\text { t-ution }\end{array}$ & $\begin{array}{l}\text { Through design } \\
\text { practice, students can } \\
\text { have better knowled-g } \\
\text { e of the market } \\
\text { requirements }\end{array}$ & $\begin{array}{l}\text { Design work is only } \\
\text { judged by the employers } \\
\text { alone, without design } \\
\text { professionals and } \\
\text { normal users' opinions, } \\
\text { there } \\
\text { are restrictions on the } \\
\text { improvement of } \\
\text { students' design }\end{array}$ \\
\hline
\end{tabular}




\begin{tabular}{|l|l|l|l|l|l|}
\hline $\begin{array}{l}\text { Kickstarte-r } \\
\text { (www.kicksta } \\
\text { rter.com) }\end{array}$ & $\begin{array}{l}\text { Crowdfu- } \\
\text { nding } \\
\text { platform }\end{array}$ & $\begin{array}{l}\text { To help bring creative } \\
\text { projects to life before } \\
\text { the deadline by } \\
\text { funding money from } \\
\text { public }\end{array}$ & $\begin{array}{l}\text { Creative } \\
\text { people who } \\
\text { need } \\
\text { money for } \\
\text { projects }\end{array}$ & $\begin{array}{l}\text { There are complete } \\
\text { project processes and } \\
\text { high innovative } \\
\text { design solutions; } \\
\text { Interactive communica } \\
\text { tion between users }\end{array}$ & $\begin{array}{l}\text { The main objective is to } \\
\text { promote the realization } \\
\text { of projects, not to } \\
\text { raise the design level }\end{array}$ \\
\hline $\begin{array}{l}\text { Behance } \\
\text { (www.behanc } \\
\text { e.net) }\end{array}$ & $\begin{array}{l}\text { Design } \\
\text {-ommuni }\end{array}$ & $\begin{array}{l}\text { To showcase and } \\
\text { discover creative } \\
\text { tyork, also to look for } \\
\text { designers }\end{array}$ & $\begin{array}{l}\text { Designers, } \\
\text { design } \\
\text { students } \\
\text { and other } \\
\text { design } \\
\text { enthusiasts }\end{array}$ & $\begin{array}{l}\text { Students can learn } \\
\text { from the complete and } \\
\text { high-quality designs } \\
\text { on it }\end{array}$ & $\begin{array}{l}\text { As there are many } \\
\text { outstanding designers, } \\
\text { students' design works } \\
\text { are hard to gain enough } \\
\text { attention }\end{array}$ \\
\hline $\begin{array}{l}\text { Coursera } \\
\text { (www.course } \\
\text { ra.org) }\end{array}$ & $\begin{array}{l}\text { Massive } \\
\text { open } \\
\text { online } \\
\text { courses }\end{array}$ & $\begin{array}{l}\text { To take free online } \\
\text { classes from top } \\
\text { universities and } \\
\text { educational } \\
\text { organizations }\end{array}$ & $\begin{array}{l}\text { Learners, } \\
\text { including } \\
\text { university } \\
\text { students }\end{array}$ & $\begin{array}{l}\text { High-quality design } \\
\text { courses, and } \\
\text { assessments } \\
\text { mentor and facilitat-e } \\
\text { learning process }\end{array}$ & $\begin{array}{l}\text { Less teacher-student } \\
\text { interaction and less } \\
\text { opportunity to practice, } \\
\text { which is quite necessary } \\
\text { for industry design } \\
\text { study }\end{array}$ \\
\hline
\end{tabular}

The analysis above shows that the existing design learning platforms have their own advantages, but not perfect for industrial design education. The existing imperfection shows that the theory and method of cloud innovation may make up for these above disadvantages.

\section{Concept of Cloud Innovation And Related Studies}

Cloud Innovation is a wide range(usually worldwide) innovation activity which reflects the swarm intelligence[1] .It connects various of knowledge and talents from worldwide to set up an normalized innovation service mode which combines scattered innovation resource. It is appropriate to be applied to students' online education platform.

Domestic and foreign researchers proposed many effective and innovative ways about learning methods of innovative design, such as expert systems, learning systems, mind mapping, brainstorming, etc. Currently, the innovative design theory, research methods and tools, reflecting the trends from closed to open[2-3].

Overseas, such as researcher Steven Tao in Carnegie Mellon University studied how to apply crowd sourcing methods to traditional education mode. If this is an appropriate way, it will allow many workers to work in a collaborative manner through the Internet, and make a way to generate income for the US economy[4].

In domestic, School of Design in South China University of Technology studied the communication of members in community and sharing of knowledge, which proposed mechanisms model of knowledge sharing in virtual design community from the perspective of teamwork[5]. School of Management in Huazhong University of Science and Technology discussed the propulsion mechanism of KIBS open innovation in three areas: creation, transition and diffusion, knowledge dissemination and absorption capacity[6].

At present, researches of cloud innovation are still in primary stage. The application of cloud innovation hasn't form a systematic theory in industrial design learning and practice, which has a huge exploration space.

\section{The application of cloud Innovation in industrial design}

To solve the above problems, based on the cloud innovation theory, we need a platform to realize online design reviews, dissemination and share, virtual display and demand-oriented collaborative design, to help students study and practice in industrial design better. Consequently, 91 Ant[7] was built to validate the idea.

\subsection{Framework and functions of cloud Innovation platform of industrial design}




\section{MATEC Web of Conferences}

\subsubsection{Design work show}

Cloud innovation platform cooperates with design schools. Students are be encouraged to upload their works of design courses and exercises. Teachers and students from different regions and different schools can do the reviews and discussions about the design online easily without long distance-travel.

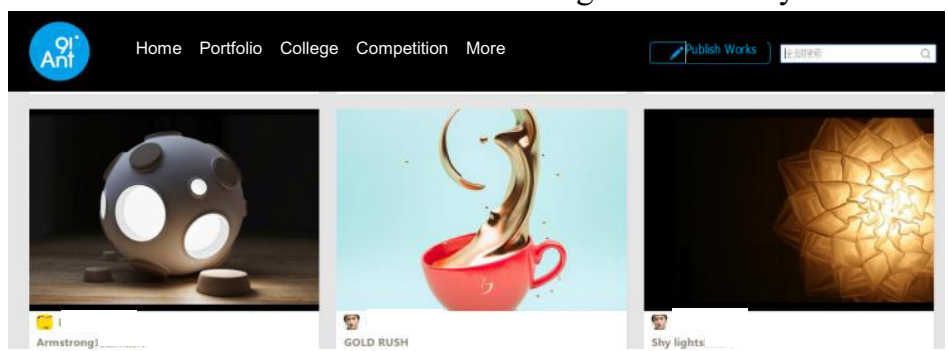

Figure 2. Page of design work show and page of uploading

\subsubsection{Design exhibition and competition}

Online graduate design exhibitions and design competitions are held to gain new users and design topics enhance user activity. Ordinary users are also invited to share their using experience and ideas of the product(as shown in figure 3), so that designers will understand what customers need. Moreover, students get more better ideas through online brainstorming and other methods. The problem of relearning and lack of communication is solved through the above ways.

\section{comments}

Figure 3. Page Of The Comments

\subsubsection{Practice in cooperation with enterprises}

Cloud innovation platform cooperates with enterprises. Enterprises call for designs of their industrial products on platform(as shown in figure 4). Students who accepted the proposition should upload the innovative ideas or preliminary design to the platform. Comments and discussions are encouraged on the platform, which are made by students and teachers of design, experienced industrial designers, and people of other relevant disciplines (such as materials science, processing technology, market, businesses,etc). Students adopt reasonable opinions and improve their design. Companies adopt the good ones and pay for them. Members participate in the discussion will get reward points depending on the contribution for the design. (as shown in figure 5) The problem of separation between education and practice is solved.

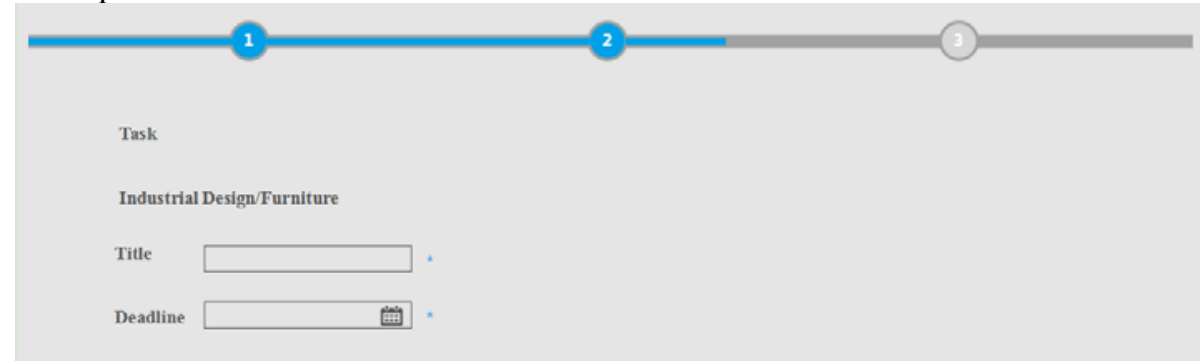

Figure 4. The Page Of Requirements Publication For Enterprises 


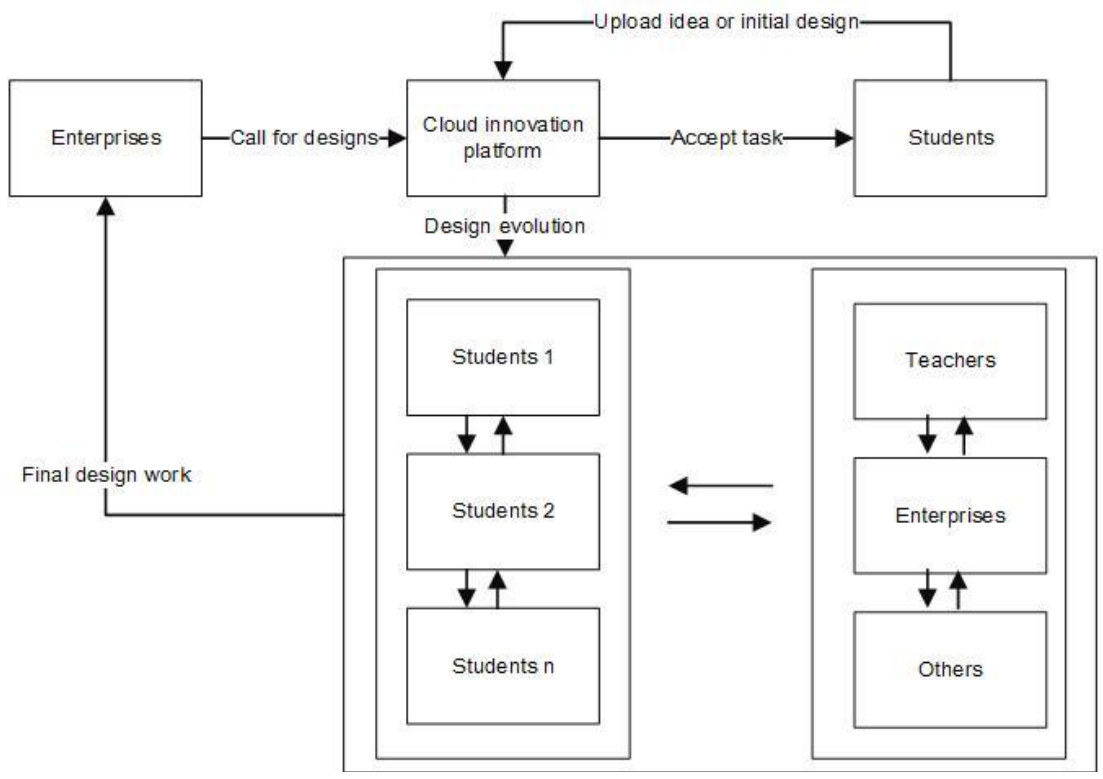

Figure 5. The Process Of Design On Cloud Innovation Platform

\subsubsection{Others}

In addition, video teaching of college courses, enterprise courses and master's lecture is also provided to supplement the theory knowledge.

In cooperation with the National Copyright Administration, cloud innovation platform protect students and designers' copyright.

Up to June 2015, the scale of China's mobile phone users reached to 594 million. As a consequence, some functional modules will be developed under mobile network, too. The convenience of mobile networks will greatly enhance the breadth and efficiency of dissemination.

\subsection{Effect of cloud Innovation platform of industrial design}

Since the establishment of 91Ant in December 2015, 732 design works has been uploaded, and design graduation show organized by Guangdong Vocational and Technical College is also welcomed. We got some user survey feedback:

Student A: From 91Ant, I got a better understanding of the needs of market.

Student B: I can visit the graduation show of other universities at home now.

Student C: This is a platform designed for students, so, our design won't be ignored here.

The monumental achievement of 91Ant demonstrated that cloud Innovation platform had some positive effect in the industrial design education for students in some degree. However, because the time of evaluation is relatively short, further studies should be needed to verify the applicability of cloud Innovation.

\section{Acknowledgements}

Project supported by National Natural Science Foundation of China(No.51 175183 )

\section{Summary}

Cloud innovation is a key to promote creativity, and the application of cloud innovation in industrial 


\section{MATEC Web of Conferences}

design education is possible to solve the problems in students' study and practice. It is a new exploration and has an important significance to promote Chinese industrial design education. However, there are still many shortconmings and omissions in this paper, and more evidences are needed to prove the theories and ideas.

\section{References}

1. Ren liMei, Huang Bin, Cloud Innovation-innovation model in the 21st Century[M]. Beijing, Chinese Communist Central Party School Press

2. TIAN Qi-hua, XIAO Ren-bin, ZHONG Yi-fang, DU Yi-xian, YANG Hong-mei, Integration of axiomatic design and theory of inventive problem solving for conceptual design [J]. Journal of Chongqing University (English Edition) [ISSN 1671-8224] (2009), 8(3):209-216

3. Jacob Goldenberg, David Mazuisky, Creativity in Product Innovation[M]. Cambridge University Press, (2003)

4. Magy Seif El-Nasr, Jacquelyn Ford Morie, Anders Drachen, A Scientific Look at the Design of Aesthetically and Emotionally Engaging Interactive Entertainment Experiences[OL], http://www.sfu.ca/ magy/conference/Emotions-chapter.pdf

5. Yang Qiang, Research of Organization Construction for Open Cloud Innovation Oriented Virtual Design Community[D]. South China University of Technology master's thesis, Guangzhou, (2014).6-10

6. He Xiaoyu, Cao Yong, Research on promoting mechanism of open innovation in knowledge intensive business service [J], Science and Science Management, (2010), (1): 59-64

7. Www.91ant.com 